\title{
Experimental Pathology and Histopathology Shared Resource
}

National Cancer Institute

\section{Source}

National Cancer Institute. Experimental Pathology and Histopathology Shared Resource. NCl Thesaurus. Code C39397.

The Experimental Pathology and Histopathology Shared Resource provides Cancer Center investigators with support in the histopathology services including animal necropsies, routine and special histological preparations, histopathologic evaluation, and assistance in experimental design. 